\title{
The Case Study of Lithuanian Voluntary National Defence Service in Intelligence in 1991-1993
}

\author{
Rokas KALVAITIS ${ }^{1}$, Audronė PETRAUSKAITÉ ${ }^{2}$ \\ ${ }^{1,2}$ General Jonas Žemaitis Military Academy of Lithuania, Department of Humanities, \\ Silo 5A, 10322 Vilnius, Lithuania

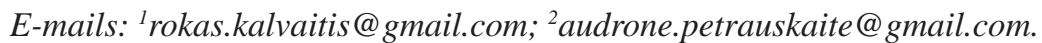

\begin{abstract}
The Voluntary National Defense Service (VNDS) of Lithuania was established in 17 January 1991 and began to operate in a difficult political and economic situation in the presence of Russian military forces deployed in Lithuania. The VNDS was tasked with ensuring the security of important state and economic entities, assisting the police in maintaining public order and territorial defense, as well as carrying out intelligence tasks throughout Lithuania. The main aim of the paper is to analyze the creation of military intelligence by the VNDS and the tasks they conducted from 1991 to 1993. Various methods were used to analyze the VNDS: case study, historical analysis, comparative historical, document analysis, data analysis and statistical content analysis. The paper establishes that the VNDS intelligence gathering structure and its development was influenced by the intelligence tasks assigned to the VNDS. The case study also reveals that the main function of the VNDS staff consisted of intelligence information gathering. In 1991, according to the VNDS standby logs analyzed in this study, 56 percent of information registered by the VNDS staff consisted of intelligence information and this information was gathered across 82 percent of Lithuanian districts. According to the data gathered in this study, it was proven that the VNDS was conducting military intelligence from 1991 to 1993 . The case study is even more relevant since the current day Lithuanian Armed Forces are returning to the national territorial defense model due to the changes in current geopolitical situation. In the future, the role of the National Defense Volunteer Force (the NDVF), equivalent to the previous VNDS, will increase significantly, as the Commander of the Lithuanian Armed Forces has appointed these forces to carry out intelligence tasks for military operations.
\end{abstract}

KEY WORDS: Voluntary National Defense Service, military intelligence, military operations, territorial defense

\section{Introduction}

The constantly changing geopolitical security environment encourages both Lithuanian politicians and the military to look for new solutions when planning national defense system. Two important changes happened in the Lithuanian Armed Forces in 2016. The first change was related to the changes in the conception of the defense of the Republic of Lithuania. In 2016 Lithuanian Armed Forces returned to the country's territorial defense model in preparation for self-defense. According Lithuanian Military Doctrine, the basis of such defense is the National Defense Volunteer Force (the NDVF) [10, p. 52 - 56]. The second change concerns the intelligence of the Lithuanian Armed Forces. The Law on the Organization of the National Defense System and Military Service, which was adopted in 2016, states that the Commander of the Lithuanian Armed Forces assigns intelligence tasks to the Armed Forces [12]. Structural and functional changes in the Lithuanian Armed Forces were prompted by the legalization of intelligence tasks of Lithuanian Armed Forces operations and the return to territorial defense. Consequently, these developments illustrate that the role of the NDVF will increase significantly in the future, as the Lithuanian Armed Forces Commander has appointed these forces to carry out intelligence tasks for military operations.

The Voluntary National Defence Service (VNDS) was established on 17 January 1991, when the Supreme Council of the Republic of Lithuania legalized the volunteer armed forces formed on the principle of voluntary participation of citizens and organized on a territorial basis [15]. The VNDS has started to act in the difficult political and economic situation of the re-establishment of Lithuania's independence while in the presence of the Soviet troops in Lithuania's territory. The VNDS's main functions were to ensure the security of important state and economic entities, to assist the state's border guard in protecting Lithuanian border and to support the police in maintaining public order and in territorial defense [8, 11]. From the very first days of its establishment, the VNDS not only had to organize the staff and territorial units but also to carry out tasks, including intelligence tasks throughout the territory

\footnotetext{
${ }^{1}$ Corresponding author.

E-mail address: eugeniusz.cieslakl@uph.edu.pl
} 
of Lithuania $[17,18,19]$.

The case study of the VNDS in the year 1991-1993 aims to investigate the intelligence history of the Lithuanian Armed Forces and to understand how intelligence tasks were performed at a critical time for Lithuania. Focusing the research on the VNDS intelligence activities in 1991 - 1993 allows to analyze and reveal hitherto unexplored issues of the Lithuanian Armed Forces:

- How was military intelligence developed and carried out in the NDVF at the beginning of 90s?

- What was the contribution and significance of the VNDS military intelligence in state defense in the first years of the restored Lithuanian state?

- How could intelligence experience be useful for Lithuanian military intelligence in the future?

The object of research. Intelligence activities of the VNDS in 1991-1993.

The aim of this study is to analyze the VNDS intelligence activities and accomplished tasks in 1991-1993, to fill a gap in modern Lithuanian military history.

The methodology of research. The study combines different methods - quantitative and qualitative. The quantitative research methods, such as case study, historical analysis, document analysis, contextual analysis and structural analysis are used to investigate and describe the development of the VNDS intelligence and the intelligence activities during 1991-1993. The quantitative survey method, content analysis of documents, helped to collect monitoring and operational logs data recorded in 1991. The logical analytical approach is used to understand the sources and approaches of the VNDS intelligence organization in its development, activities, and intelligence terminology used at that time. A triangulation approach helped to design the study, which combines qualitative and quantitative methods, allows to gain a deeper understanding of the VNDS as an exploration phenomenon between 1991 and 1993 and to create the framework for the future of the VNDS intelligence activities.

The results of this study should encourage further discussions on VNDS military intelligence, and its contribution to the organization of territorial defense. The study also provides ground for further research in the fields of military intelligence, the VNDS intelligence and the state intelligence. The example of VNDS military intelligence in 1991-1993 is an impetus for further research of the history of the Lithuanian Armed Forces and research of modern Lithuanian Armed Forces intelligence.

\section{Establishment and Activity of Lithuanian Intelligence Services 1990-1993: Historical Approach}

There is not much research on modern Lithuanian intelligence. This is due to both the secrecy of the intelligence services themselves and the limited access to primary sources to the investigators. Nevertheless, this is not a completely unexplored area as shown by studies discussed below.

Arvydas Anušauskas' research covers the issues of interwar Lithuanian intelligence issues as well as the KGB activities in Lithuania from 1921 until 1991. The research of interwar Lithuanian intelligence provides an opportunity to better understand the circumstances of how the intelligence of independent Lithuania was created [1]. The rich historical material informs why the Division of the Department of State Defense was named the 2nd Department during the restoration of Lithuania's independence. The title of the 2nd Department is identical to the title of the 2nd Department of the Pre-war Lithuanian General Staff [1, p. 318-321]. Both of the 2nd Departments' functions were to organize and execute intelligence. Anušauskas concludes that Lithuanian intelligence emerged as military intelligence and its purpose was to ensure the national security of the state. A component of military intelligence was so-called "front intelligence," which interacted directly with military units operating on the front $[1$, p. 16, 29]. Anyšauskas' research in the field of KGB activities in Lithuania allows one to understand the complex conditions under which the Republic of Lithuania and its military structures were rebuilt in 1990. Those conditions were revealed in Anyšauskas' research, such as methods by which KGB was functioning, which methods of intelligence, surveillance, interrogations and alike were practiced and how the Soviets established their rule in Lithuania [2].

Vaidotas Urbelis in his article "The system of Lithuanian Intelligence" states that the system of Lithuanian intelligence was formed from 1991 to 1993. During these years, army and military intelligence were functioning under one intelligence system. Since 1994, the operational level, army intelligence, and strategic, military, have been separated. Afterwards, the distribution of functions within Lithuania intelligence institutions has not changed substantially. On his point of view, the names and functions of modern Lithuanian intelligence services have become very similar to the intelligence system of Lithuania between 1935 and 1940 [20, p. 222]. The researcher explains the term military intelligence, by emphasizing that such a division into military and non-military intelligence was made by defining the scope of activity. Military intelligence collects and analyzes information on foreign military capabilities in its own and other countries. The scientist singles out army intelligence as an element of military intelligence, which is responsible for supporting combat operations [20, p. 221-226].

Gintaras Bagdonas discusses how and to what extent the secret services must be under control of democratic society [4]. The researcher provides a generalized definition of intelligence encompassing its strategic, operational, 
and tactical levels. He gives the definition of the intelligence as one of the forms of state activities: “... intelligence can be defined as an ongoing activity or process in which information about foreign countries and the world around us is collected, processed and after the analysis is provided to consumers" [3, p. 12]. Bagdonas reviews the areas of activity of intelligence services by distinguishing the methods of information collection and the nature of activities [3, p. 14-16]. Bagdonas also defines the tasks of counterintelligence and states that "military counterintelligence is solely responsible for the security of military information in the defense sector, for preventing foreign intelligence activities focused on the country's defense, as well as, responsible for supporting foreign intelligence activities as an integrated part of the intelligence service" $[3,15]$.

All authors provide their own definitions of intelligence and military intelligence; nevertheless, they all came on agreement on the following:

- Intelligence is an ongoing activity / process of collecting information about foreign countries and the world around it and providing analysis to users.

- Military counterintelligence focuses on the country's defense, supports foreign intelligence activities, is responsible for the security of military information in the defense sector and prevents foreign intelligence activities. The term military counter-intelligence is defined in terms of its scope and purpose of the activity.

- Military intelligence concentrates on the country's defense, collects and evaluates information on the current and projected capabilities of foreign armies in its own and other countries' territories. The term military intelligence is defined in terms of its scope and purpose of the activity.

\section{The Analysis of the VNDS Intelligence Activity in 1991-1993: the Results of Qualitative Research}

This qualitative research aimed to analyze the development of VNDS military intelligence and the tasks performed in 1991-1993, by revealing the specific features and peculiarities of this intelligence activity in the first years of Lithuania's independence and actualizing historical experience in the context of modern Lithuanian territorial defense.

During the qualitative research, primary sources were searched and collected in the archives of the NDVF Headquarters, 8th NDVF Unit and Lithuanian Ministry of National Defense. There these documents were found: orders of General Director of the Department of National Defense, the orders of the VNDS Chief of Staff, the protocols of the VNDS staff and units, and others [9]. After assessing the veracity, reliability and accuracy of the information contained in them, a study of the activities of the VNDS was carried out, focusing on its intelligence activities.

In 1991 - 1993 the military intelligence structure of the VNDS command staff consisted of: the Information and Communication Divisions of the VNDS staff and the Operational Squad (March-May 1991); Information Division, Staff Company Operations Squad and Intelligence Division (June 1991-January 1992); Information Division (February 1992 to May 1993); Information Division (Counterintelligence) and Operational Division (Intelligence) (June-December 1993). Following the approval of the first temporary structure of the VNDS, there were no plans to establish intelligence services at the staffs of the VNDS units (March-May 1991). Subsequently (i.e. from June 1991 to December 1993), the military intelligence structure of the VNDS units consisted of: the Communications and Information Service (June 1991 - June 1992); Information Service (June 1992 to June 1993); Operational divisions, subdivisions and groups (July - December 1993). Table 1.

Military intelligence tasks of the Voluntary National Defence Service (VNDS) in 1992

\begin{tabular}{|c|c|c|}
\hline Military intelligence task & Operation type & Objects \\
\hline $\begin{array}{l}\text { Monitoring and collection of } \\
\text { information }\end{array}$ & $\begin{array}{l}\text { - Stationary posts; } \\
\text { - Mobile patrols; } \\
\text { - Reconnaissance flights; } \\
\text { - Radio intelligence. }\end{array}$ & $\begin{array}{l}\text { - Russian troops locations; } \\
\text { - Russian military personnel; } \\
\text { - Military objects; } \\
\text { - Military equipment; } \\
\text { - Railway stations; } \\
\text { - Roads. }\end{array}$ \\
\hline Training for special tasks & $\begin{array}{l}\text { Training for monitoring; } \\
\text { Training for information } \\
\text { collection. }\end{array}$ & VNDS soldiers and volunteers. \\
\hline
\end{tabular}

According to military documents, the VNDS performed the intelligence tasks by the VNDS military intelligence personnel, the VNDS staff divisions, soldiers of Operational Squads and Intelligence Divisions, and volunteers of the VNDS national units from 1991 to 1993. In 1991 - 1993 the main tasks of military intelligence 
were to gather the information about the activities of USSR force structures in Lithuania (in 1991) and to collect the information on Russian military units deployed in the territory of Lithuania (in 1992-1993) (Table 1).

The structural and functional changes in the VNDS intelligence service were related to the final withdrawal of the Russian Armed Forces in 1993. Until August 1993 the main intelligence task of the VNDS soldiers and volunteers was to monitor Russian military units; nonetheless, fundamental transformations in the VNDS military intelligence have already taken place in 1992-1993. This transformation resulted in the separation of intelligence and counterintelligence functions in the VNDS military intelligence, the improvement of intelligence functions and structure in the VNDS organization, the creation of an education and training system for volunteers and soldiers in units (Fig 1). A system for the transmission, management and coordination of intelligence was set up: the VNDS Staff Information Division had to provide information to the National Defense Department, Information Service in 1991, to the Immunity Service of the Ministry of National Defense in 1992 and to the Intelligence and Counterintelligence Department of the Ministry of National Defense in 1993.

\section{VNDS STAFF}

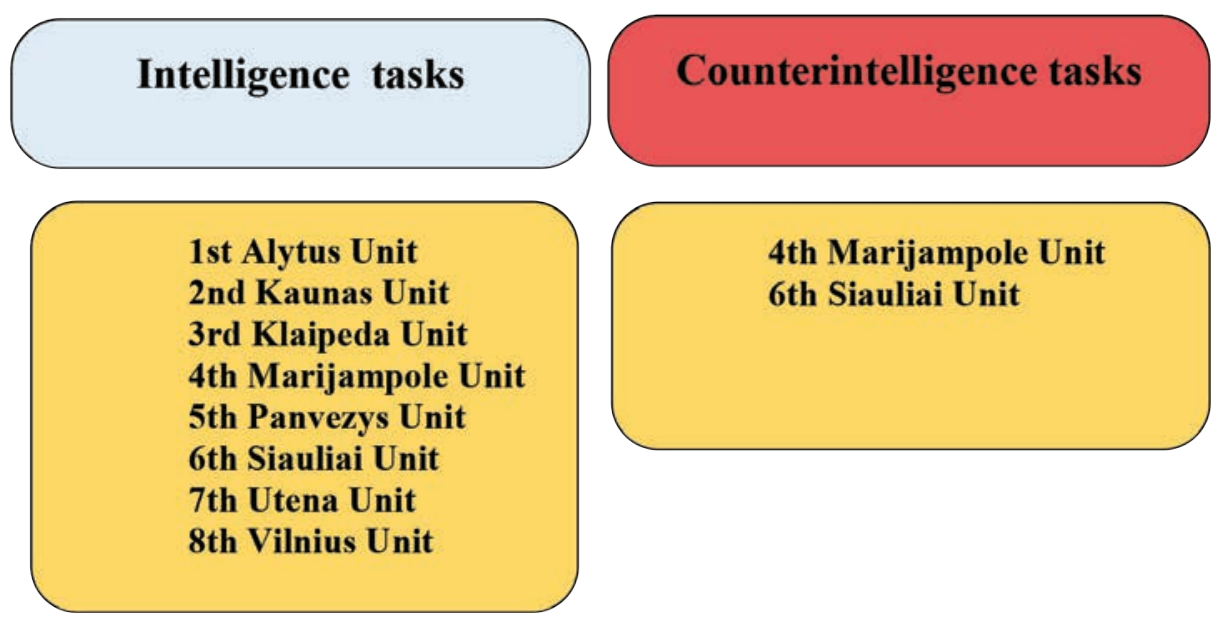

Fig 1. Distribution of military intelligence tasks within Voluntary National Defense Service in 1993.

Based on the qualitative analysis of archival documents of the Lithuanian Defense System in the period 1991-1993, it could be stated that the VNDS military intelligence system was formed in the period 1991-1993. It was during this period that the main work on the development of the VNDS military intelligence system took place, as following:

- The system and methodology for collecting and transmitting the VNDS intelligence data was developed in the period 1992 - 1993;

- $\quad$ The functions of the VNDS intelligence unit were defined;

- Not only a system of military intelligence but also a system of counter-intelligence was developed and implemented;

- The VNDS military intelligence system was integrated into the system of Lithuanian National defense.

- The processes of development and change of the VNDS intelligence's structure that took place in 1991 - 1993 were conditioned by the intelligence tasks assigned to the VNDS forces and the changed political situation in the Republic of Lithuania.

\section{The Analysis of the VNDS Intelligence Activity in 1991-1993: the Results of Quantitative Research}

The aim of quantitative research on the VNDS staff's standby logs in 1991 was to determine the nature of the information recorded in 1991 [13, 14, 15]. The statement of the quantitative study was formulated: "In 1991 the VNDS activities were directly related to the collection of intelligence information on the USSR's military units deployed in Lithuania". This made in order to find out the intelligence information which was registered in the standby logs of the VNDS staff and identified the nature of this received information (the operationalization of the quantitative research statement is presented in Table 2). 
During the research, it was found that the archives of the VNDS staff have not completely survived through the period of 1991-1993. However, the VNDS standby logs were found, which registered the information transmitted from the units and other informants. The VNDS standby logs also included intelligence information about the actions of the USSR military in the territory of the Republic of Lithuania in 1991. In this way, the size of the study population was defined in time, that is, from 17th January 1991 until 31st December 1991. Summarizing the three VNDS standby logs of 1991, the sample size is set as a period of 180 days. To calculate the sample size when the population size is known, the formula was chosen [5]:

$$
n=\frac{N 1.96^{2} p q}{\varepsilon^{2}(N-1)+1.96^{2} p q}
$$

Where:

- $\quad \mathrm{N}$ - size of the population;

- 1.96 - value of the standardized normal part with a confidence level of $\alpha=0.05$;

- $\quad \mathrm{p}$ - expected probability of an event occurring in the population (usually $\mathrm{p}=0.5$ );

- $\quad \mathrm{q}$ - expected probability of occurrence that the symptom will not appear in the population $(\mathrm{q}=1-\mathrm{p}=0.5)$.

Table 2.

The operationalization of the quantitative research statement

\begin{tabular}{|c|c|c|}
\hline Statement & Definition & Assumptions \\
\hline \multirow[t]{2}{*}{$\begin{array}{l}\text { In } 1991 \text { the VNDS activities were } \\
\text { directly related to the collection } \\
\text { of intelligence information on the } \\
\text { USSR's military units deployed in } \\
\text { Lithuania. }\end{array}$} & $\begin{array}{l}\text { Intelligence } \\
\text { information }\end{array}$ & $\begin{array}{l}\text { - Information about the USSR military } \\
\text { accounted for most of the daily } \\
\text { information recorded in the standby logs } \\
\text { of the VNDS staff. } \\
\text { - TThe VNDS staff received intelligence } \\
\text { information from the entire territory of } \\
\text { the Republic of Lithuania. }\end{array}$ \\
\hline & Intelligence activity & $\begin{array}{l}\text { - IIn } 1991 \text { the VNDS soldiers collected and } \\
\text { reported more intelligence information to } \\
\text { the VNDS staff than other informants } \\
\text { - IIn } 1991 \text { the conduct of intelligence } \\
\text { activities was related to the process of } \\
\text { creating the VNDS units and structure }\end{array}$ \\
\hline
\end{tabular}

Following the results of quantitative study, the statement "In 1991 the VNDS activities were directly related to the collection of intelligence information on the USSR's military units deployed in Lithuania" was partially confirmed because all the assumptions were approved.

The first assumption "Information about the USSR military accounted for most of the daily information recorded in the standby logs of the VNDS staff" was confirmed. According the results of research, intelligence information accounted for 56 percent of all information received and registered by the VNDS staff duty guard while the remaining received and registered information accounted for 44 percent (Table 3).

The second assumption "The VNDS staff received intelligence information from the entire territory of the Republic of Lithuania" was partially confirmed. It was discovered that the intelligence information recorded in the journals of the VNDS staff guard was received from 38 districts of Lithuania, which accounted for 82 percent of the territory of the state. The main part of the information (i.e. 72 percent) was received from the city of Vilnius, where the Soviet units and their military objects were concentrated (Fig 2). 
The nature of information received by Voluntary National Defence Service staff in 1991

\begin{tabular}{|c|c|}
\hline Variable group & Number in a data set \\
\hline Information about the USSR's military & 1196 \\
\hline The VNDS units reports & 400 \\
\hline Duty reports & 183 \\
\hline The VNDS activities & 115 \\
\hline Other information & 135 \\
\hline Phone Calls (organizational) & 64 \\
\hline Clarification of information & 30 \\
\hline Total: & 2123 \\
\hline
\end{tabular}

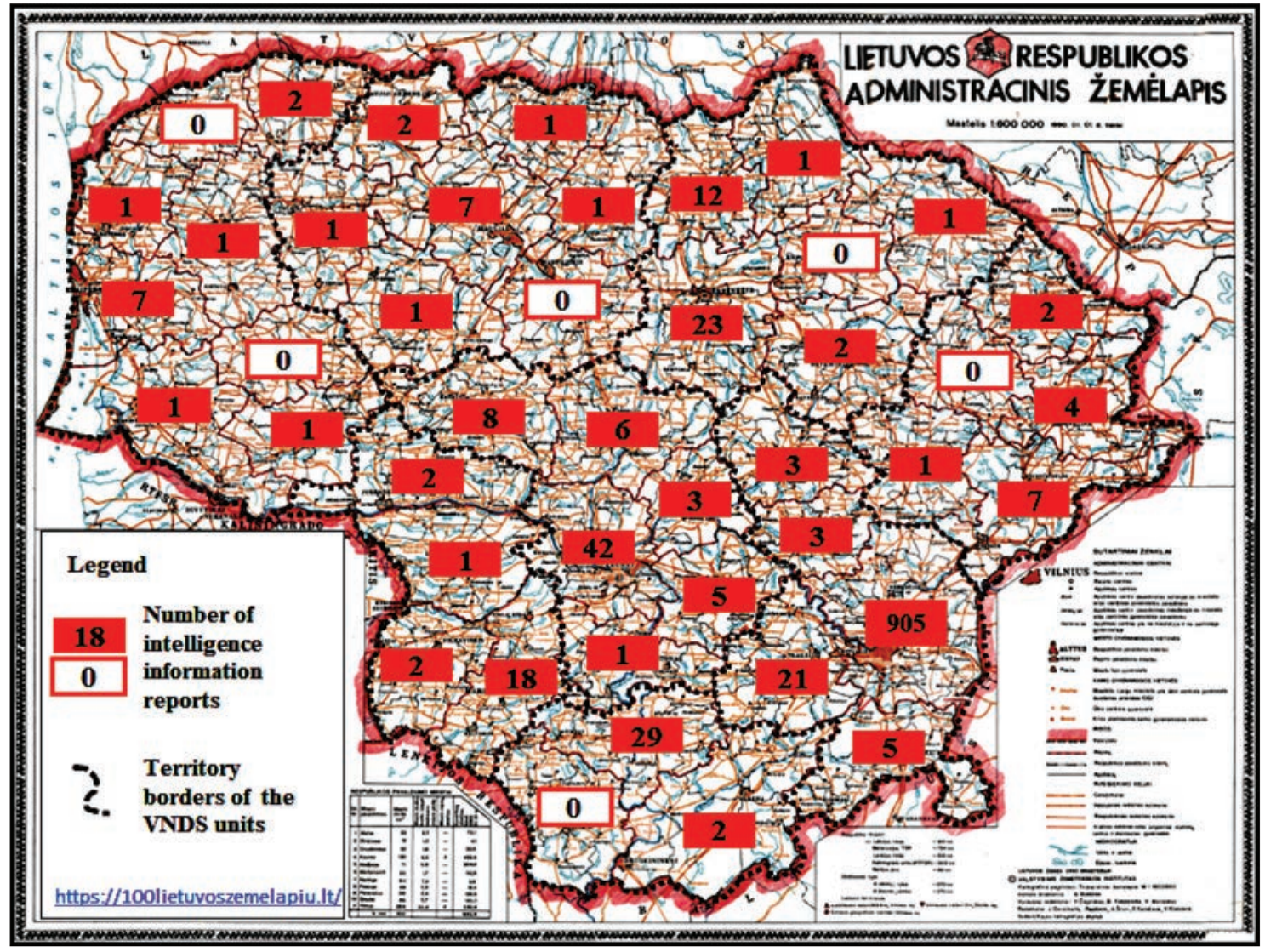

Fig 2. Intelligence information received by the VNDS staff from 44 districts of Lithuania.

The third assumption "In 1991 the VNDS soldiers collected and reported more intelligence information to the VNDS staff than other informants" was neither confirmed nor rejected, as only 49 percent of intelligence informants was identified. Nevertheless, it was found that the VNDS units reported 27 percent of intelligence information about the USSR military. Other intelligence information about Soviet troops, their military objects and activities was received from the inhabitants of Lithuania (13 percent), governmental institutions ( 7 percent) and other informants ( 2 percent) (Fig 3).

The fourth assumption "In 1991 the conduct of intelligence activities was related to the process of creating the VNDS units and structure" was confirmed. The number of intelligence information received from the VNDS units increased due to the introduction of the guard duty in the VNDS units (Fig 4). It is obvious that the number of intelligence reports received from the VNDS units started to grew up in May 1991 when the force structure began to start its formation and the VNDS Staff began to perform intelligence tasks. Before this, other informants (i.e., citizens, soldiers, governmental institutions, etc.) provided intelligence information to the VNDS and/or to the Department of State Defense. 
The results of quantitative research approved the results qualitative research about the intelligence activities of the VNDS in 1991-1993.

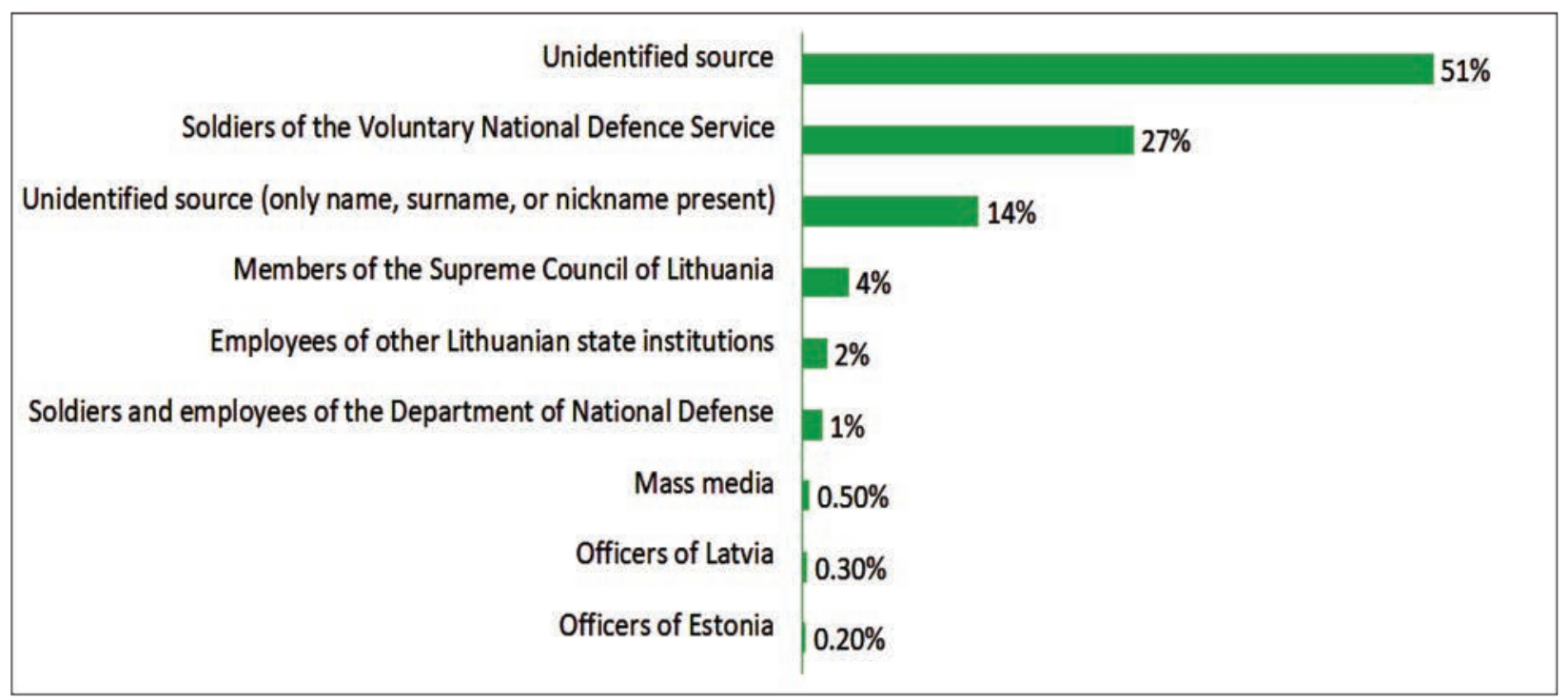

Fig 3. The intelligence informants on the USSR Armed Forces deployed in Lithuania in 1991.

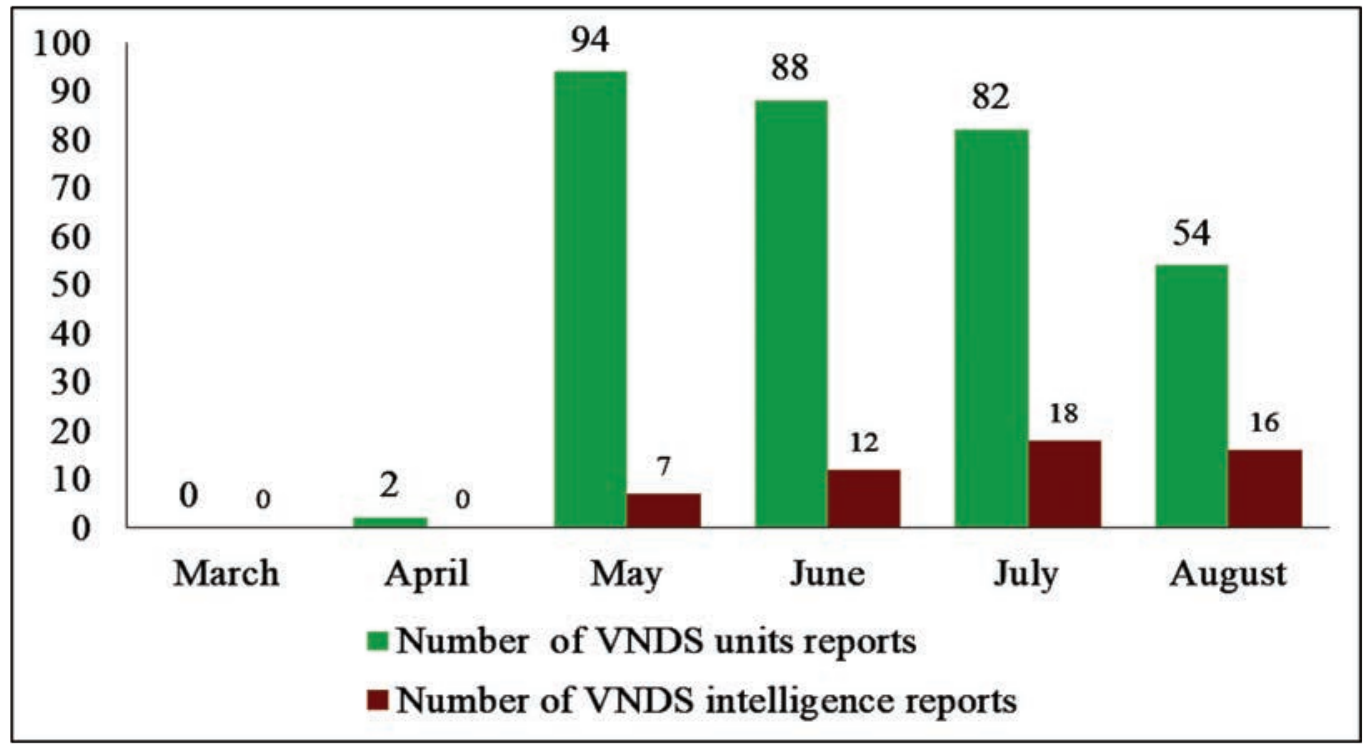

Fig 4. The number of intelligence reports received from the Voluntary National Defense Service Units (March - August, 1991).

\section{Conclusions}

Lithuania's independence was restored in 1990, but its fortification took place in 1991-1993, while USSR military units were still deployed in Lithuania. The power structures of the USSR carried out provocations against the institutions and citizens of the Republic of Lithuania. When the withdrawal of the Russian army began in 1992-1993, the Russian army carried out provocations, destroyed the property what had to be transferred to Lithuanians, and illegally traded weapons, amongst others. This lasted until August 1993 until the last unit of the Russian army left the territory of Lithuania.

The establishment of intelligence tasks caused the creation and subsequent development of the VNDS's military intelligence and counterintelligence structure since its inception. In 1991 more than half of the registered information of the VNDS staff consisted of intelligence. The intelligence tasks conducted by the VNDS led to the 
development of the military intelligence structure within the VNDS in 1991-1993.

One of the main tasks of VNDS was to gather information about the USSR force structures, including USSR Armed Forces, OMON and KGB. In 1991 - 1993, the VNDS carried out military intelligence throughout the territory of the Republic of Lithuania. The VNDS conducted these activities: the interception of radio conversations of the USSR force structures, covert surveillance of the USSR's, since December 1991 Russia's, military objects and the movement of military equipment and personnel, aerial reconnaissance during surveillance flights, and monitoring of the removal of Communist Party archives.

The VNDS developed the methodology for gathering intelligence information. The training of full-time intelligence staff of the VNDS and VNDS units started in 1992. Intelligence tasks were established for times of combat readiness and martial law. In 1993, intelligence and counterintelligence functions were separated and training of volunteers for reconnaissance tasks within the VNDS units was launched.

The creation of the VNDS units enabled the National Defense System to receive intelligence information from the entire territory of Lithuania. Lithuanian citizens and Lithuanian state institutions also provided intelligence to the VNDS Staff. From 1991 to 1993, the VNDS military intelligence was carried out under the conditions of occupation. The example of the VNDS intelligence activities is valuable for the modern Lithuanian army. The VNDS case study can inform on how intelligence should be organized and conducted under conditions of occupation.

\section{References}

1. Anušauskas, A. Lietuvos žvalgyba 1918-1940. Vilnius: Versus aureus, 2014.//In English: Anusauskas, A. Lithuanian Intelligence in 1918-1940. Vilnius: Versus aureus, 2014.

2. Anušauskas, A. KGB Lietuvoje. Slaptosios veiklos bruožai. Kaunas: Spaudos praktika, 2008.//In English: Anusauskas, A. KGB in Lithuania. The features of secret activities. Kaunas; Spaudos praktika, 2008

3. Bagdonas, G. Slaptujų žvalgybos tarnybų vaidmuo ir kontrolẻ demokratinèje valstybëje. Kardas, 2 (419), 2006, p. 10 - 16. // Bagdonas, G. (2006). The role and control of secret intelligence services in a democratic state. Kardas, 2 (419), 2006, p. 10 - 16.

4. Bagdonas, G. Žvalgyba turi būti aktyvi, laiku reaguoti ị galimas grèsmes. Krašto apsauga, 18 (147), 2008, p. $3-6$. // In English: Bagdonas, G. The Intelligence must be proactive, responding in a timely manner to potential threats. Krašto apsauga, 18 (147), 2008, p. 3 - 6.

5. Balaišis, A., Surgailis, G. Rusijos kariuomenès išvedimas iš Lietuvos dokumentuose (Knezys, S., ats. red.): [dokumentų rinkinys], Vilnius: Generolo Jono Žemaičio Lietuvos karo akademija, 2005. // In English: Balaišis, A., Surgailis, G. Withdrawal of the Russian army from Lithuania in documents (Knezys, S., Ed.). Vilnius: Generolo Jono Žemaičio Lietuvos karo akademija, 2005.

6. Bekešienè, S. Duomenų analizès SPSS pagrindai. Vilnius: Generolo Jono Žemaičio Lietuvos karo akademija, 2015. // In English: Bekešienė, S. Basics of data analysis SPSS. Vilnius: Generolo Jono Žemaičio Lietuvos karo akademija, 2015.

7. Butkevičius, A., Jezerskas, Č., Jurkevičius, A., Leišis, A., Stankovičius, I., Urbas, V., Užurka, J., Vaitkaitis A. ir Vegelevičius Z. Lietuvos krašto apsaugos sistemos atkūrimas 1989 - 1993 metais. (Užurka, J., leid. sud.). Vilnius: Eugrimas, 2015. // In English: Butkevičius, A., Jezerskas, Č., Jurkevičius, A., Leišis, A., Stankovičius, I., Urbas, V., Užurka, J., Vaitkaitis A. ir Vegelevičius Z., (2015). Restoration of the Lithuanian national defense system in 1989-1993. (Užurka, J., Ed.). Vilnius: Eugrimas, 2015.

8. Dragūnaitis, P. Pamąstymai apie žvalgybą. Pranešimas seminare Teritorinė gynyba. Vilnius: Lietuvos karo akademija, Mokslo centras p. 37 - 38. // In English: Dragūnaitis, P. Reflections on intelligence. Presentation at the seminar Territorial Defense.Vilnius: Lietuvos karo akademija, Mokslo centras, 1995, p. 37 - 38.

9. KASP archyvas, ap. 1, b. 3, 4, 33, 34, 36, 42, 43, 89, 93, 95. // In English: NDVF archive, in. 1, cases 3, 4, 33, 34, 36, 42, 43, 89, 93, 95.

10. Lietuvos karinè doctrine (2016), Lietuvos kariuomenès vado $2016 \mathrm{~m}$. balandžio $22 \mathrm{~d}$. įsakymas Nr. V-570. (2016). Vilnius: Lietuvos kariuomenès Karo kartografijos centras. // In English: Lithuanian Military Doctrine (2016). Commander of the Lithuanian Armed Forces 2016 April 22, Order No. V-570. Vilnius: Military Cartography Center of the Lithuanian Armed Forces.

11. Kariuomenès žvalgybos doktrina, KAM ND 2936, Lietuvos kariuomenės vado 1998 m. rugsèjo 17 d. ịsakymas Nr. 1035 (1998). Vilnius: Lietuvos Respublikos krašto apsaugos ministerija.// In English: Doctrine of the Armed Forces Intelligence (1998). Commander of the Lithuanian Armed Forces in 1998. September 17 Order No. 1035.

12. Lietuvos Respublikos Krašto apsaugos sistemos organizavimo ir karo tarnybos ịstatymo Nr. VIII-723 2, 12, 13 , 18, 20, 21, 28, 29, 44, 53, 55, 59, 62, 65, 65 1 , 67, 68 ir $77^{2}$ straipsnių pakeitimo ịstatymas: Lietuvos Respublikos Seimo 2016 m. spalio 3 d. ịstatymas Nr. XII-2722. (2016). Teisés aktu registras, (Nr. 26833). // In English: 
Law of the Republic of Lithuania on the Organization of the National Defense System and Military Service No. VIII-723 Law Amending Articles 2, 12, 13, 18, 20, 21, 28, 29, 44, 53, 55, 59, 62, 65, 651, 67, 68 and 772: October 3 Law No. XII-2722. Register of Legal Acts, (No. 26833). https://www.e-tar.lt/portal/legalAct. html?documentId=a3b80640ab3d11e6a6f98c1425a5ffa8

13. Savanoriškosios krašto apsaugos tarnyba. Informacijos registravimo žurnalas (Budejjimo SKAT štabe žurnalas. II206). Pradėtas $1991 \mathrm{~m}$. vasario 21 d. baigtas balandžio 1 d. (1991a). KASP archyvas, b. 33, 1.1 - 45.// In English: Voluntary National Defense Service. Logbook of information (Journal of Standby at NDVF Staff. II-206). Started in 21 February 1991. Completed on April 1 1991. NDVF archive, c. 33, p. 1 - 45.

14. Savanoriškosios krašto apsaugos tarnyba. Informacijos registravimo žurnalas (Budejjimo SKAT štabe žurnalas. II-353). Pradètas 1991 m. balandžio 4 d. baigtas rugpjūčio 18 d. (1991b). KASP archyvas, b. 34, 1. 1 - 88.// In English: Voluntary National Defense Service. Logbook of information (Journal of Standby at NDVF Staff. II353). Started in 4 April 1991. Completed on 18 August 1991. NDVF archive, c. 34, p. 1 - 88.

15. Savanoriškosios krašto apsaugos tarnyba. Informacijos registravimo žurnalas (Operatyvinio budinčiojo darbo žurnalas. II-354). Pradètas 1991 m. gruodžio 26 d. baigtas 1992 m. kovo 10 d. (1991). KASP archyvas, b. 36, l. 1 - 48.// In English: Voluntary National Defense Service. Logbook of information (Journal of Standby at NDVF Staff. II-354). Started in 26 December 1991. Completed on 10 March 1992. NDVF archive, c. 33, p. 1 - 48.

16. Lietuvos respublikos Savanoriškosios krašto apsaugos tarnybos įstatymas: Lietuvos respublikos Aukščiausioji Taryba - Atkuriamasis Seimas 1991 m. sausio 17 d. įstatymas Nr. I-958. (1991). Lietuvos aidas, (Nr. 14-0). // In English: Law on the Voluntary National Defense Service of the Republic of Lithuania: The Supreme Council of the Republic of Lithuania - the Restorative Seimas, 17 January 1991. Law No. I-958. (1991). Lietuvos aidas, (Nr. 14-0). https://e-seimas.lrs.lt/portal/legalAct/lt/TAD/TAIS.1064?jfwid=-c3cv15gkw

17. Surgailis, G. Krašto apsaugos departamentas ir jo veikla 1990 - 1991 m. Karo archyvas XIX, t. 19, Generolo Jono Žemaičio Lietuvos karo akademija, 2004, p. 414-481.// In English: Surgailis, G. Department of National Defense and its activities 1990 - 1991. Karo archyvas XIX, t. 19, Generolo Jono Žemaičio Lietuvos karo akademija, 20047, p. 414-481.

18. Surgailis, G. Lietuvos Respublikos Aukščiausiosios Tarybos gynyba $1991 \mathrm{~m}$. sausio dienomis (Krašto apsaugos departamento padalinių veikla). 1991 metu sausio 13-oji Lietuvoje naujausiu moksliniu tyrimu kontekste (Ragauskas, A. ir Truska, L. sud.): [mokslinių straipsnių rinkinys], Vilniaus pedagoginis universitetas, 2006, p. 66 - 74.// In English: Surgailis, G. (2006). Defense of the Supreme Council of the Republic of Lithuania in 1991 January (activities of the divisions of the Department of National Defense). The 13th of January 13, 1991 in the context of the latest research in Lithuania (Ragauskas, A. and Truska, L. ed.): [Collection of scientific articles]. Vilniaus pedagoginis universitetas, 2006, p. $66-74$

19. Surgailis, G. Rusijos kariuomenès išvedimas 1990 - 1993. Vilnius: Krašto apsaugos ministerijos Leidybos ir informacinio aprūpinimo tarnyba, 2005.// In English:Surgailis, G. Withdrawal of the Russian army 1990 - 1993. Vilnius: Krašto apsaugos ministerijos Leidybos ir informacinio aprūpinimo tarnyba, 2005.

20. Urbelis, V. Lietuvos žvalgybos sistema. Lietuvos metiné strateginé apžvalga 2008 (Vitkus, G., ats. red.), Generolo Jono Žemaičio Lietuvos karo akademija, 2009, p. 215-245.// In English: Urbelis, V. The System of Lithuanian Intelligence. Lietuvos metinè strateginė apžvalga 2008 (Vitkus, G., ats. red.), Generolo Jono Žemaičio Lietuvos karo akademija, 2009, p. 215-245. 